\title{
INOVASI PEMBUATAN PEMPEK BAGI PELAKU USAHA KECIL PEMPEK DI KOTA PALEMBANG
}

\author{
A.D. Murtado ${ }^{1)}$ \\ 1)Program Studi Teknologi Pangan Universitas Muhammadiyah Palembang \\ Corresponding author: A.D. Murtado \\ E-mail : murtado.asyari@yahoo.com
}

Diterima 17 September 2020, Direvisi 03 Oktober 2020, Disetujui 05 Oktober 2020

\begin{abstract}
ABSTRAK
INOVASI PEMBUATAN PEMPEK BAGI PELAKU USAHA KECIL PEMPEK DI PALEMBANG. Bertujuan untuk mensosialisasikan dan memberikan bimbingan teknis dan manajemen inovasi pembuatan pempek berupa tepung pempek bagi pelaku usaha pempek di kota Palembang. Pempek dikenal sebagai makanan tradisional kota Palembang yang dibuat dari campuran ikan giling dan tepung tapioca dan disajikan dengan cuko pempek. Keterbatasan SDM yang terampil dalam pembuatan pempek, dan keterbatasan umur simpan pempek, menjadikan pempek terbatas untuk didistribusikan ke daerah yang lebih luas. Pada tahun 2016 (Murtado) berhasil menciptkan tepung pempek sebagai bahan pembuatan pempek yang terbuat dari ikan giling dan tepung tapioka yang diolah menjadi campuran kering homogen. Dengan tepung pempek, membuat pempek menjadi lebih mudah dan cepat. Umur simpan tepung pempek mencapai dua tahun sehingga penanganan dan distribusi lebih mudah dan sederhana. Kegiatan berupa pembinaan langsung pembuatan tepung pempek bagi mitra yang ditunjuk dan bersedia mengikuti kegiatan ini. Kegiatan dilakukan dengan lima tahap, yaitu: 1) seleksi calon peserta, 2) tatap muka penjelasan sekitar tepung pempek, 3) pembuatan tepung pempek dan 4) pembuatan pempek berbahan tepung pempek. Setelah 7 hari melakukan pembinaan dan pelatihan, dihasilkan peserta yang terampil secara teknis dan minat yang semakin besar terhadap pengembangan usaha pempek berupa tepung pempek.
\end{abstract}

Kata kunci: Pempek; inovasi; usaha kecil.

\begin{abstract}
PEMPEK-MAKING INNOVATIONS FOR SMALL BUSINESS PLAYERS OF PEMPEK IN PALEMBANG. Aiming to socialize and provide technical guidance and management of innovation in making pempek in the form of pempek flour for pempek entrepreneurs in Palembang city. Pempek is known as a traditional Palembang food made from a mixture of ground fish and tapioca flour and served with cuko pempek. Limited skilled human resources in making pempek, and limited shelf life of pempek, make it limited for pempek to be distributed to a wider area. In 2016 (Murtado) succeeded in creating pempek flour as an ingredient for making pempek which is made from ground fish and tapioca flour which is processed into a homogeneous dry mixture. With pempek flour, making pempek becomes easier and faster. The shelf life of pempek flour is up to two years, making handling and distribution easier and simpler. Activities in the form of direct guidance for making pempek flour for partners who are appointed and willing to participate in this activity. The activity was carried out in five stages, namely: 1) selection of prospective participants, 2) face-to-face explanation about pempek flour, 3) making pempek flour and 4) making pempek made from pempek flour. After 7 days of coaching and training, participants who were technically skilled and had greater interest in developing the pempek business in the form of pempek flour were produced.
\end{abstract}

Keywords: Pempek; innovations; small business.

\section{PENDAHULUAN}

Empek-empek adalah makanan khas daerah Palembang yang dibuat dari campuran ikan giling dan tepung tapioka, yang dibuat dengan cara pengulenan antara ikan dan tepung tapioka dengan perbandingan tententu. Hasil pengulenan di rebus atau dikukus sampai terjadi gelatinasi. Empek-empek dapat disajikan dengan cara langsung hasil rebusan atau digoreng terlebih dahulu. Saat ini pempek sudah dikenal hampir di seluruh nusantara dan menjadi makanan pavorit baik bagi msyarakat kota Palemabang maupun masyarakat di Nusantara. Di kota Palembang penjual pempek terus tumbuh dan berkembang mulai dari pedagang asongan yang dijajakan dengan berjalan kaki, bersepeda dan seperda motor, pedagang warung rumahan sampai pedagang 
toko besar yang berada di jalan jalan besar dan juga di mall mall. Bagi masyarakat kota Palembang pempek menjadi makanan sehari hari dan mudah ditemukan serta menjadi menu pilihan dalam setiap acara, dari mulai rapat dan pertemuan lainnya hingga pesta pernikahan.

Secara alami pempek mampu berumur hingga 2 hari dalam suhu kamar, sedangkan dalam penyimpanan beku mampu bertahan hingga 4 bulan (A D Murtado \& Verayani, 2014). Untuk kebutuhan pengiriman ke tempat yang jauh, maka umur simpan menjadi hal penting diperhatikan. Mutu yang tetap baik sangat penting dijaga selama penyimpanan baik penyimpanan gudang maupun selama transfortasi. Selama ini para pengusaha pempek, untuk kebutuhan pengirimannya menggunakan tapioka atau minyak sebagai pelumur pempek dalam kemasan. Pempek ditaburi tapioka atau minyak hingga tertutup rata selanjutnya di kemas. Cara ini ternyata mampu bertahan hanya 3 sampai 4 hari dalam suhu kamar (Murtado, A D \& Verayani, 2015). Beberapa pedagang lain telah melakukan pemakuman dalam kemasan plastik. Cara ini terbukti mampu memperpanjang umur simpan lebih lama. Jumlah pecinta pempek yang terus meningkat, belum didukung oleh inovasi yang mampu membantu mempermudah dalam memenuhi pasar di luar kota Palembang, terlebih untuk pemasaran internasional. Ketersediaan bahan dan pengrajin terampil masih menjadi kendala utamanya.

Murtado,A D (2016) telah menemukan bahan pembuat pempek dengan nama tepung pempek. Tepung pempek dibuat dari campuran homogen ikan giling dan tepung tapioka yang dikeringkan. Dengan tepung pempek, pembuatan pempek menjadi lebih mudah dan cepat. Umur simpan tepung pempek dapat mencapai dua tahun. Pendistribusian tepung pempek sangat mudah dan tidak memerlukan penanganan husus. Tepung pempek menjadi solusi kesulitan pembuatan pempek. Selain itu tepung pempek juga menjadi solusi dalam pendistribusian dan perluasan pasar pempek. Dalam laporannnya menyebutkan bahwa proses pembuatan pempek berbahan tepung pempek adalah jauh lebih singkat dan cepat dibanding pembuatan pempek cara biasa.

Tahun 2018 tepung pempek sempat mengisi pasar pasar modern di pulau Sumatera dan menjadi oleh oleh yang menarik bagi turis mancanegara. Beberepa keunggulan tersebut tepung pempek diharapkan mampu membantu meningkatkan pasar bagi para pedagang pempek, terutama pasar di luar kota palembang bahkan ekspor. Terkait hal ini, pengabdi berharap tepung pempek ini menjadi salah satu produk andalan penghasilan masyarakat pengrajin pempek di kota Palembang. Salah satu upayanya adalah memberikan pelatihan pembuatan tepung pempek kepada pengrajin pempek. Diharapkan melalui pelatihan ini akan melahirkan pembuat tepung pempek yang terampil dan sekaligus menjadi pengembang usaha tepung pempek.

\section{METODE}

Empat tahap yang dilakukan dalam kegiatan pengabdian ini.

Tahap I, mencari calon anggota yang memiliki minat untuk mengikuti pelatihan dan juga minat untuk mengambangkan usaha tepung pempek. Calon ini disebut sebagai mitra. Syarat untuk menjadi mitra adalah: 1) pengarajin pempek dengan sekala sangat kecil dan sederhana, 2) memiliki minat untuk mengikuti pelatihn pembuatan tepung pempek, 3) memiliki minat untuk mengembangkan usaha tepung pempek. Jumlah mitra dibatasi dua pengrajin dan tiap pengrajin adalah satu orang.

Tahap II, pelaksanaan pelatihan.

Pelatihan pembuatan tepung pempek didahului dengan tatap muka berupa penjelasan tentang pengenalan tepung pempek, bahan pembuat tepung pempek, meliputi mutu dan ciri ciri ikan giling segar dan tepung tapioka bermutu. alat alat pembuat tepung pempek, cara kerja alat, sanitasi selama proses pembuatan tepung pempek. Proses pembuatan tepung pempek meliputi: pencampuran ikan giling dan tepung tapioka hingga homogen. Cara pemabuatan pempek berbahan tepung pempek.

Tahap III, pembuatan tepung pempek. Dilakukan dengan cara praktek langsung. Kedua peserta dibimbing langsung dalam proses pembuatan tepung pempek dari mulai persiapan alat dan bahan hingga seluruh tahapan hingga dihasilkan tepung pempek dan dilanjutkan dengan pengemasannya. Pembuatan tepung pempek meliputi: 1)pencampuran dan pengadukan dengan menggunakan mixer hingga homogen, 2) pengeingan dengan oven yang dilengkapi baling- baling, 3) penyaringan, 4) pengemasan.

Tahap IV adalah pembuatan pempek berbahan tepung pempek yang meliputi: 1) pencampuran air mendidih dengan tepung pempek, 2) pengadukan hingga kalis, 3) pembentukan, 4) perebusan.

\section{HASIL DAN PEMBAHASAN}

Tahap I, calon mitra yang diperoleh adalah dua orang dari dua pengrajin (pedagang) pempek dengan pendidikan SMA. Berpengalaman sebagai pengrajin dan pedagang pempek lebih dari lima tahun. Mereka memiliki minat yang tinggi terhadap wirausaha tepung pempek dan juga 
berkeinginan untuk mengembangkan usahanya. Mereka juga terampil dalam pembuatan pempek yang baik dan disukai konsumen. Mereka juga bersedia untuk mengikuti seluruh tahapan pelatihan.

Tahap II. Tatap muka dengan materi penjelasan tentang pengenalan tepung pempek, bahan pembuat tepung pempek, meliputi mutu dan ciri ciri ikan giling segar serta. alat alat pembuat tepung pempek, cara kerja alat, cara malakukan penimbangan bahan (Gambar 1), cara pembuatan tepung pempek, menjaga sanitasi selama proses pembuatan tepung pempek dan pembuatan pempek berbahan tepung pempek

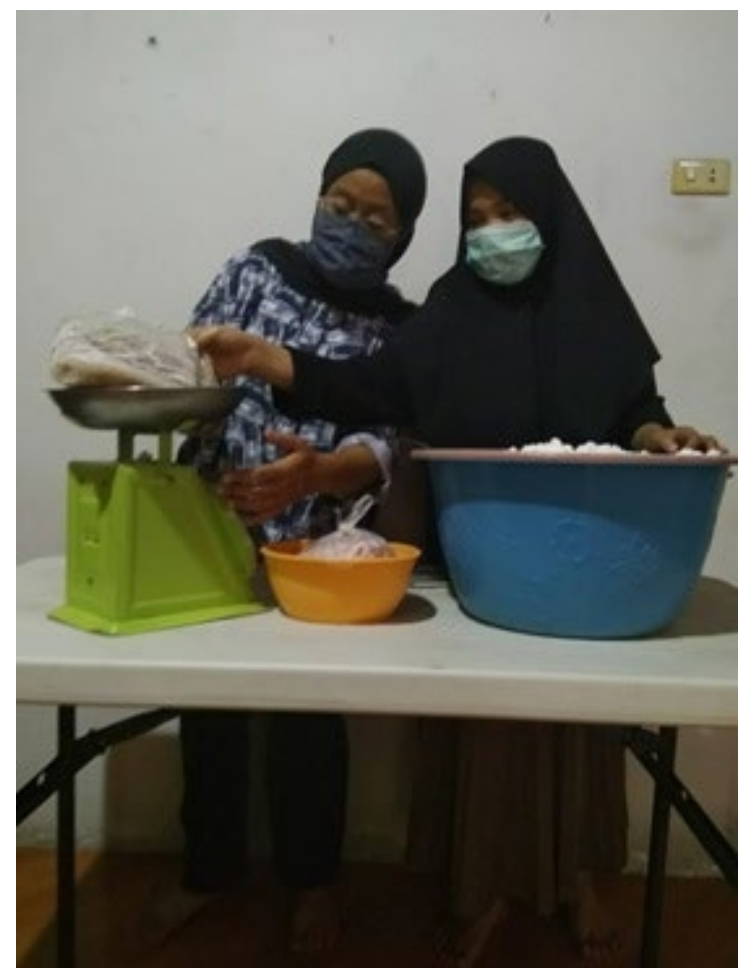

Gambar 1. Mempelajari cara penimbangan.

Hari pertama, setelah dilakukan evaluasi, peserta belum memahami dengan baik dari seluruh materi yang disampaikan.. Seluruh materi pada tahap II, adalah pengulangan materi hari pertama. Di hari ke dua dihasilkan bahwa kedua peserta memahami dan menguasai seluruh materi yang disampaikan. Mereka mengetahui apa itu tepung pempek, sifat fisik dan kimia tepung pempek, keunggulan tepung pempek sebagai bahan pembuatan pempek, serta peluang untuk mengembangkan usaha tepung pempek. Mereka juga mengetahui bagaimana cara memilih ikan yang bagus (Gambar 2), mengetahui produk tepung tapioka yang bermutu, mengetahui dan memahami pentingnya menjaga sanitasi selama proses mulai dari bahan, alat, hingga hasilnya, mengetahui dan memahami dalam mempersiapkan alat dan bahan, tata letak alat dan bahan. Mereka juga megetahui dan memahami bagaimana cara mengopersionalkan alat agar aman bagi pekerja dan awet bagi peralatannya. Pada tahap ini juga tumbuh semangat dan minat yang besar untuk mengambangkan usaha tepung pempek.

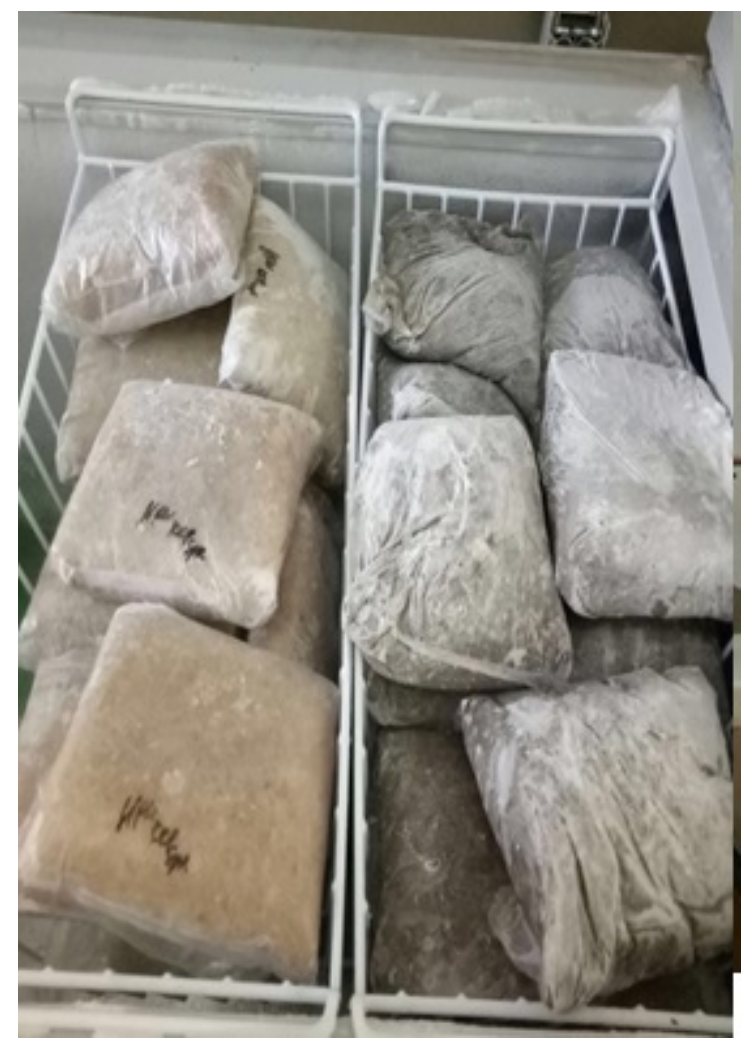

Gambar 2.Mempelajari mutu daging ikan

Tahap III, Pembuatan tepung pempek. Peserta terlebih dahulu dimintakan untuk mempersiapkan bahan dan alat yang akan digunakan sesui dengan kebutuhan. Langkah ini berjalan dengan baik dan lancar sesuai keharusannya. Setelah seluruh bahan disiapkan, peserta mulai melakukan proses pembuatan tepung pempek. Kegiatan pembuatan tepung pempek diawali dengan proses pencampuran dan pengadukan ikan giling dengan tepung tapioka seperti yang terlihat pada Gambar 3. Proses pencampuran dan pengadukan dilakukan dengan sangat baik dan hati hati dan dihasilkan bahan campuran dengan mutu yang bagus 


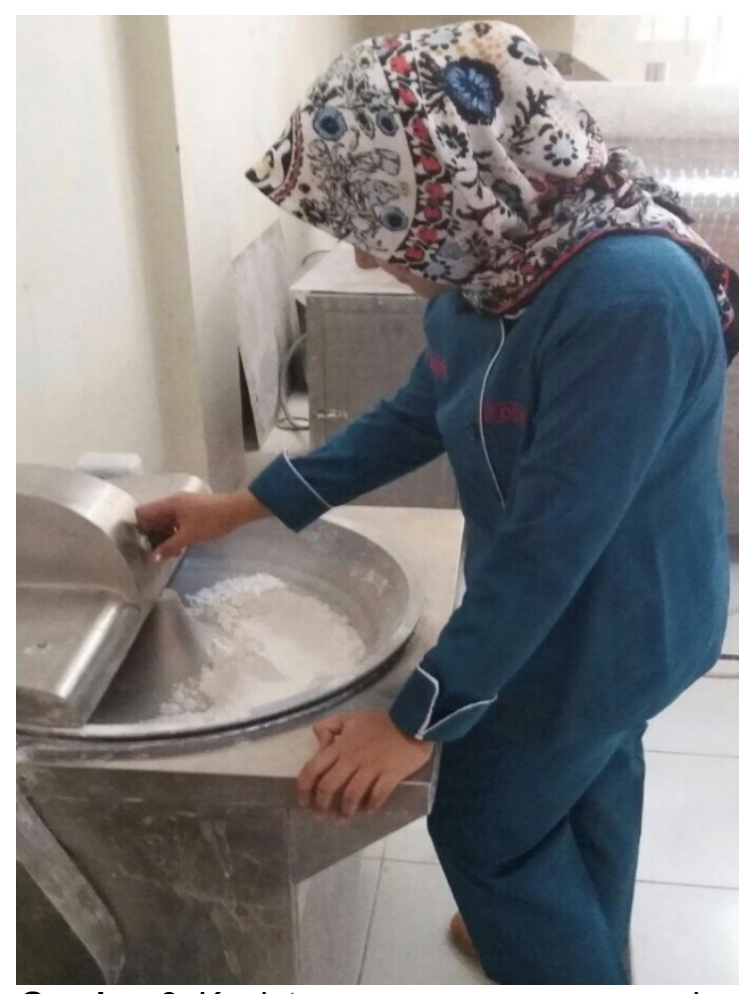

Gambar 3. Kegiatan proses pencampuran dan pengadukan daging ikan giling dengan tepung tapioka

Setelah proses pencampuran dan pengadukan selesai dan sebelum melakukan proses selanjutnya, peserta diberikan penjelasan tentang ciri-ciri bahan hasil campuran yang bagus, baru kemudian dilanjutkan dengan kegiatan proses pengeringan.

Kegiatan proses pengeringan diawali dengan terlebih dahulu menghidupkan pemanas oven. Setelah oven tercapai suhu standar dan stabil, selanjutnya mamasukan bahan ke dalam oven. Proses ini dilakukan dengan sangat hati hati. Seluruh bahan dimasukkan ke dalam oven sesuai kapasitasnya seperti yang ditunjukkan pada Gambar 4.

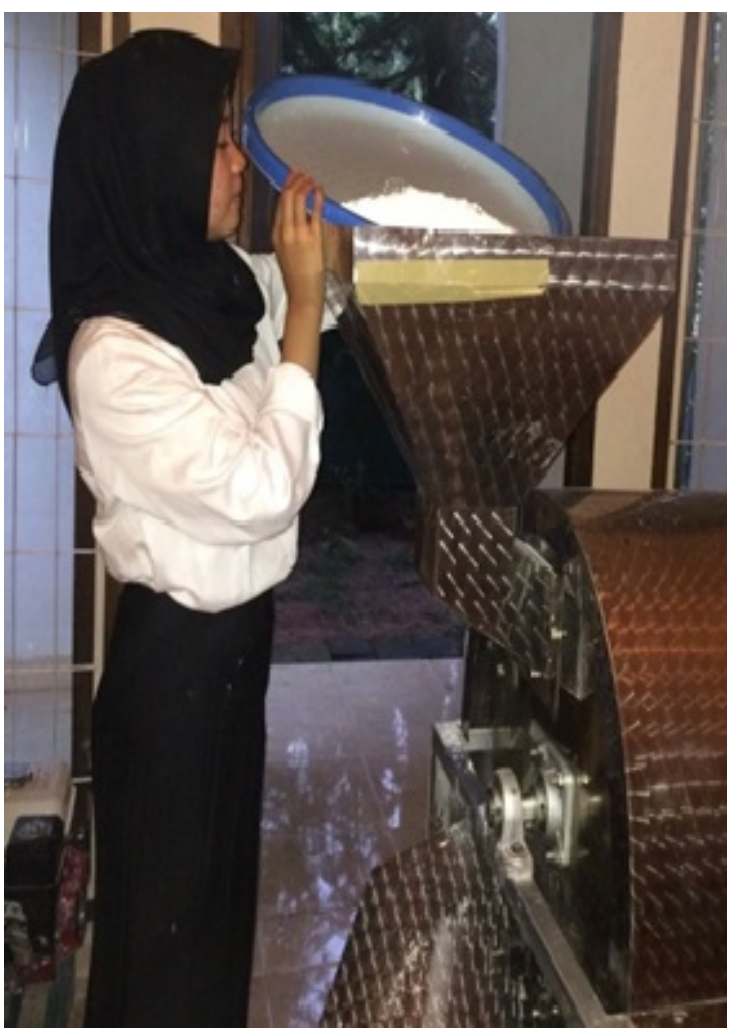

Gambar 4. Kegiatan proses pemasukan bahan campuran ke dalam oven.

Setelah seluruh bahan cmpuran masuk, mesin dihidupkan dan mulai proses pengeringan (Gambar 5).

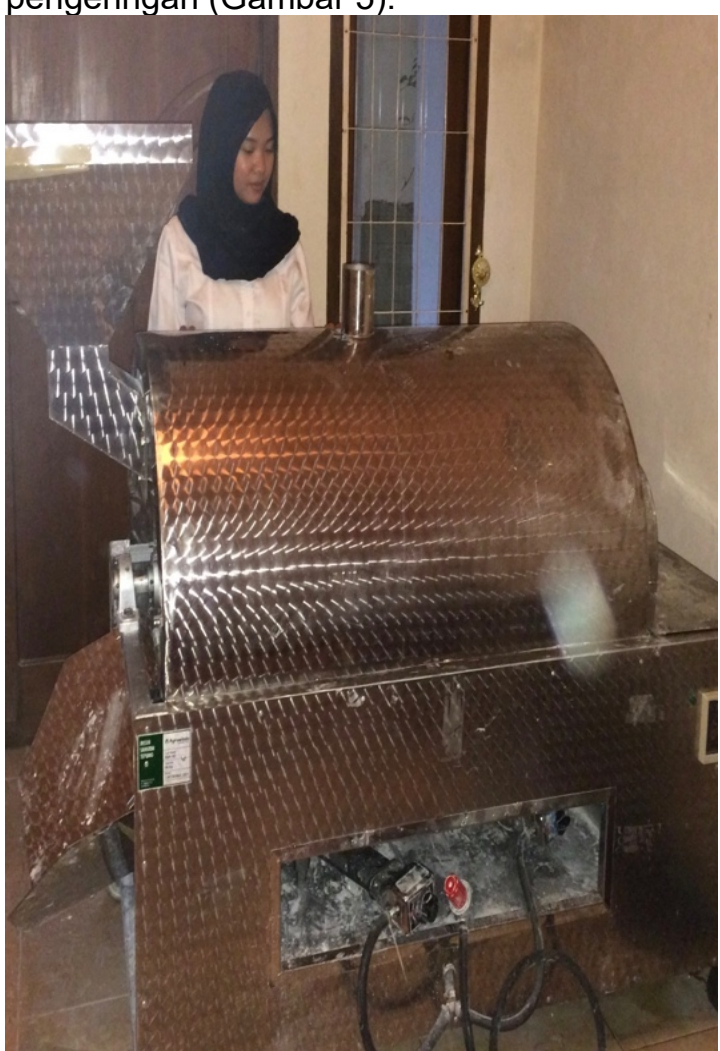

Gambar 5. Kegiatan proses pengeringan tepung pempek. 
Proses pengeringan dilakukan selama lebiih kurang 8 jam. Selama proses pengeringa, peserta melakukan pengecekan suku dan pengecekan bahan setiap 2 jam sekali. Setelah cukup kering, selanjutnya bahan dikeluarkan dan didinginkan selama satu malam.

Hari berikutnya kegiatannya adalah proses penyaringan bahan dan dilanjutkan dengan pengemasan (Gambar 6 dan Gambar 7)

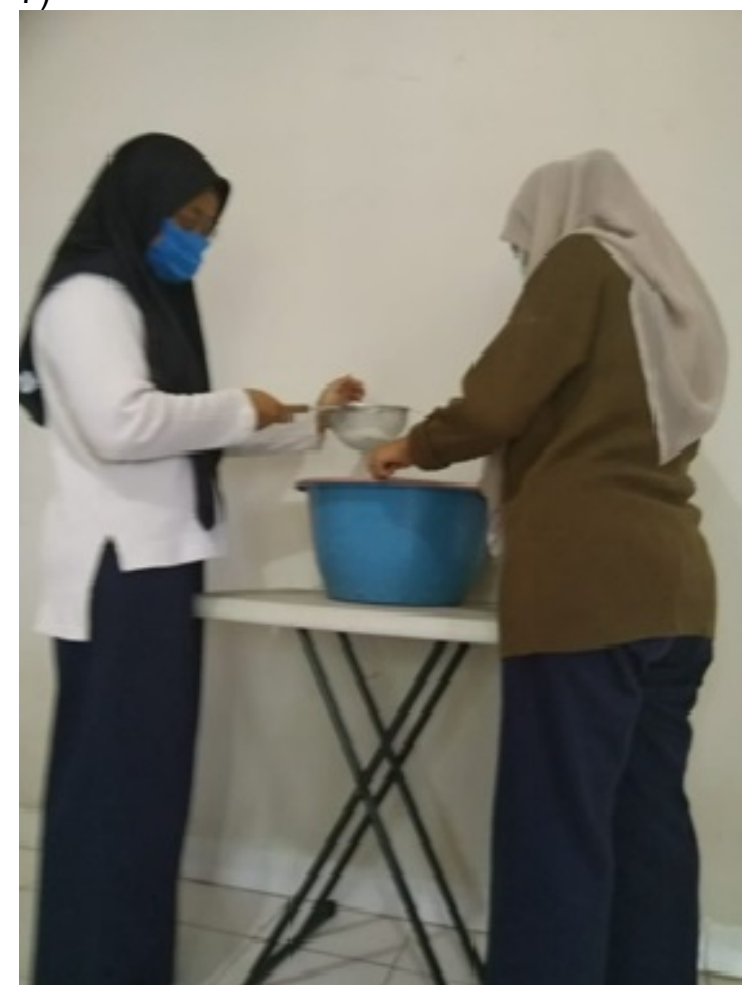

Gambar 6. Peserta melakukan penyaringan

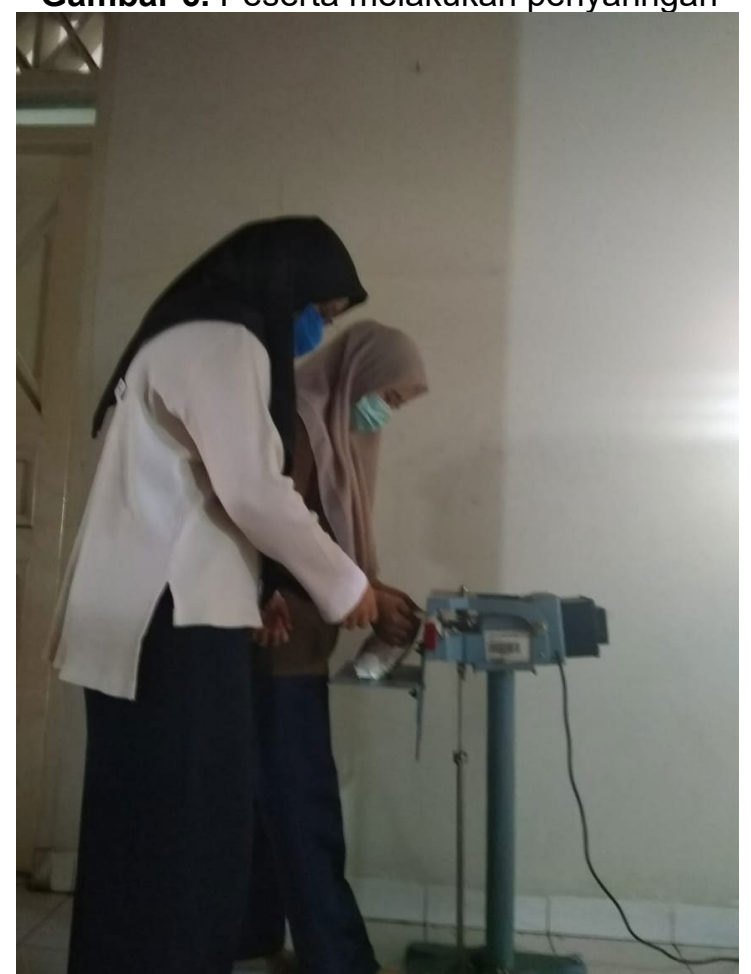

Gambar 7. Peserta melakukan penyegelan
Untuk memperdalam penguasaan teknis pembutan tepung pempek, pelatihan dilakukan kembali di hari berikutnya. Pada tahap ini proses pembuatan tepung pempek berjalan baik dan lancer.

Peserta melakukan persiapan bahan dan alat dengan baik dan benar dan meletakkannya ditempat yang tepat, menghidupkan peralatan dengan benar, menggunakan alat dengan benar,melakukan proses dengan benar, melakukan kontrol dengan benar, menjaga sanitasi dengan benar dan menjaga keselamatan kerja dengan benar.

Tahap IV, pembuatan pempek berbahan tepung pempek. Peserta memiliki latar belakang sebagai pembuat pempek, sehingga pada tahap ini semua berjalan dengan sangat baik dan lancar (Gambar 8).

Melakukan penambahan air mendidih dengan cara dan ukuran yang benar, pengulenan yang benar, lama perebusan dengan waktu yang tepat, melakukan pendinginan dengan benar. Untuk mengukur tingkat konsistensi mutu pempek yang dihasilkan, pembuatan pempek dilakukan tiga kali. Dari tiga kali ulangan tersebut diihasilkan produk pempek dengan kriteria yang relatif sama. Dengan pengalaman sebagai pengrajin dan pedagang pempek, peserta sangat memahami dan mengetahui mutu pempek yang baik dan disukai konsumen.

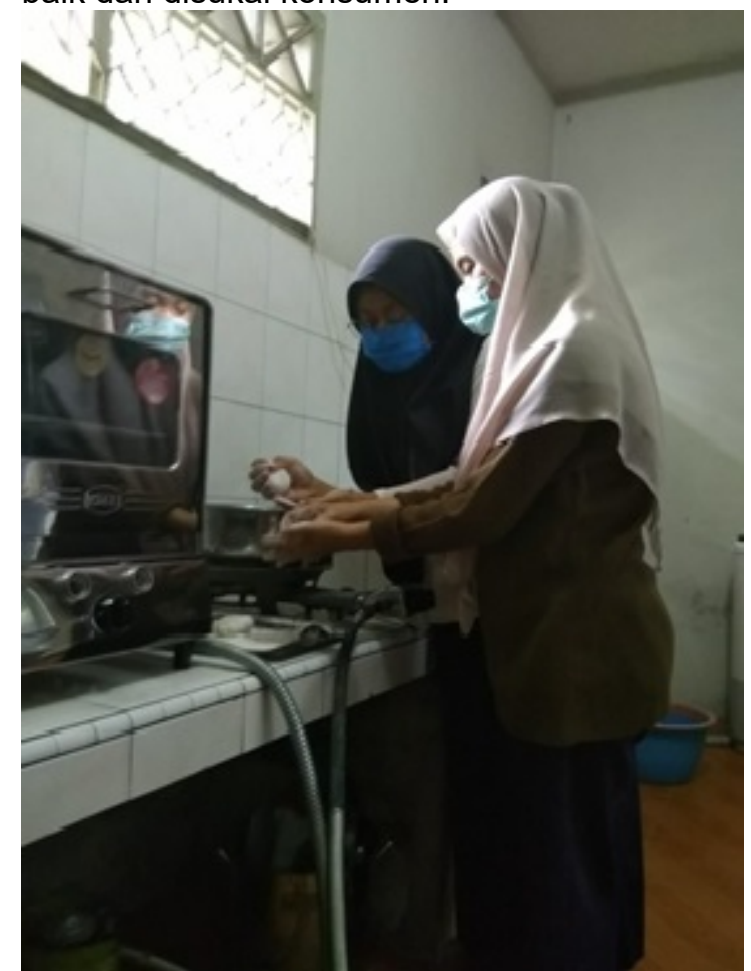

Gambar 8. Peserta membuat pempek berbahan tepung pempek 


\section{SIMPULAN DAN SARAN}

\section{Simpulan}

Palembang

Kegiatan pembinaan dan pelatihan pembuatan pempek ini memberikan dampak yang positif bagi peserta. Tepung pempek adalah produk yang memiliki peluang ekonomi tinggi yang harus ditumbuh kembangkan untuk menciptakan pasar yang lebih luas sebagai solusi dari keterbatasan pempek tradisional.. Peserta memiliki minat dan harapan untuk mengembangkan usaha keluarga industri tepung pempek. Latar belakang peserta sebagai pengrajin dan penjual pempek, mendukung terhadap kelancaran dan kesuksesan program ini.

\section{Saran}

Perlu ada dukungan pemerintah dalam menumbuh kembangkan industri tepung pempek untuk mengangkat ekonomi masyarakat pengrajin dan penjual pempek dan sekaligus menasionasasikan bahkan mengintrnasionalisasikan pempek sebagai makanan tradisional kota Palembang.

\section{UCAPAN TERIMAKSIH}

Diucapkan terimakasih kepada Dekan Fakultas Pertanian Universitas Muhammadiyah Palembang yang telah memberikan dukungan penuh pada kegiatan ini. Ucapan terimaksih juga disampaikan kepada mitra yang telah berpartisipasi aktif dalam kegiatan ini.

\section{DAFTAR RUJUKAN}

Murtado, A D, Dasir. and, \& Verayani, A. (2015). Ability of Coating Materials in Maintaining Empek-Empek Quality during Vacum Storage. Food Science and Quality Management, 44(2014), 36-41.

Murtado, A D. (2017). The process design of pempek flour making. Bahan Ajar. Tidak dipublikasikan. Fakultas Pertanian Universitas Muhammadiyah Palembang

Murtado, A Dasir, \& Verayani, A. (2014). Hedonic Quality of Empek-Empek with the Addition of Kappa Carrageenan. Food Science and Quality Management ISSN, 32, 12-19.

Murtado, A D, \& Verayani, A. (2014). Hedonic Quality of Empek-Empek with the Addition of Kappa Carrageenan.and Flour Porridge. Food Science and Quality Management ISSN, 34, 1 - 6.

Murtado, A D, (2016). Tepung pempek sebagai bahan pengembangan produk pempek. 27-32.Bahan Ajar. Tidak Dipublikasikan. Fakultas Pertanian Universitas Muhammadiyah 